\title{
Selected International Receptor-Based Air Quality Standards
}

\author{
Leighton S. Cochran and Roger A. Pielke \\ Colorado State University \\ Fort Collins, Colorado
}

Endre Kovács

Institute for Environmental Protection

Budapest, Hungary

\begin{abstract}
The ambient air quality standards (AAQS) of twenty-one nations for eight commonly regulated substances are presented. Many countries are adding a receptor-based component to their air quality management, which traditionally have been emission oriented. Automation of air quality monitoring stations has meant that local air quality evaluation can now be more easily achieved. However, a majority of countries have no active air quality standards (emission or receptor-based) or ambient air quality monitoring. One possible monitoring procedure is outlined and the variation in international standards is discussed.
\end{abstract}

As a consequence of the severely polluted air over the cities of Europe during and after the Industrial Revolution, the simplest method for governments to regulate the polluters was at the source: the elevated stack. The Alkali Works Act of 1863 in England ${ }^{1}$ was intended to curtail the smoke emissions by 95 percent and, in fact, was reasonably successful. However, this was not the first attempt at an emissions-based air quality standard. As early as 1273 the use of coal in London was restricted by the Smoke Abatement Act on the basis of being "prejudicial to health" and in 1307 a Royal Proclamation by Edward I ceased the use of "sea coal" (high sulfur coal) in the tradesman's furnaces of London.

The true importance of the atmosphere's role in air quality management was not fully grasped until as late as 1952 when an inversion blanketed London for five days and caused four thousand deaths. Similar "air pollution episodes" were becoming more common in all industrialized nations, and an historical sample is presented in Table I.

The legacy of such early tragedies in air quality control prompt discussion of three important issues for the world community as we enter the $21^{\text {st }}$ century:

1. The majority of nations have no emission-based, or ambient (receptor) based standards for air quality.

2. Why do those nations with air quality legislation continue to stipulate an emission-based standard which largely ignores the atmospheric link between the source and the biological user of that air at the downstream receptor site?

3. Are the current emission-based standards, or even the more recent receptor-based approach, really monitored with any vigor by the responsible government authorities?

Copyright 1992 -Air \& Waste Management Association
From the perspective of a total global responsibility an emission approach is quite adequate; it reduces the total quantity of deleterious material put into our atmosphere. However, for the communities near the pollution source this approach is generally not satisfactory.

\section{International Survey}

Many nations have no active air quality standards at all and so the choice between emission-based or ambient air quality becomes a moot point. A total of thirty-three countries were investigated in this study and if the air quality standards were not accessible in the publications readily available, $1,2,4,5$ then the relevant responsible government authority was contacted directly. In some cases direct contact was also required to check on what turned out to be erroneous data in some publications. As may be expected, there is considerable variation in the ambient air quality standards enforced around the world.

The general lack of ambient air quality standards, and in many cases the total lack of any air quality standards, has resulted in only twenty-one nations being represented in Table II. It should be noted that some nations choose to accept the World Health Organization's (WHO) recommendations for air quality. For example, the island nation of Singapore has standards that are generally emission-based, but the air quality is continuously monitored by a government agency; the WHO standards are adopted as a benchmark. Thus, Table II lists the receptor-based, or ambient air quality standards, for eight of the most commonly legislated pollutants over a variety of averaging periods used by various nations.

Some nations stipulated standards for substances that were particular to their dominant industries, but generally not considered of legislative significance elsewhere. For 
Table I. Some notable air quality episodes over the last century. 2,3

\begin{tabular}{|c|c|c|c|}
\hline Location & Date & Pollutants & $\begin{array}{l}\text { Excess } \\
\text { Deaths }\end{array}$ \\
\hline London, England & Dec $9-11,1873$ & $\mathrm{SO}_{2}$ & 650 \\
\hline London, England & $\operatorname{Jan} 20-29,1880$ & $\mathrm{SO}_{2}$ & 1176 \\
\hline $\begin{array}{l}\text { Meuse Valley, } \\
\text { Belgium }\end{array}$ & Dec 1-5, 1930 & $\begin{array}{l}\mathrm{SO}_{2} \\
\mathrm{Up} \text { to } 0.1 \mathrm{~g} / \mathrm{m}^{3}\end{array}$ & 63 \\
\hline $\begin{array}{l}\text { Donora, PA } \\
\text { USA }\end{array}$ & Oct $26-31,1948$ & $\begin{array}{l}\mathrm{SO}_{2} 2 \\
\mathrm{Up} \text { to } 0.005 \mathrm{~g} / \mathrm{m}^{3}\end{array}$ & 20 \\
\hline London, England & Nov 26-30, 1948 & $\mathrm{SO}_{2}$ (particles) & 700 \\
\hline Poza Rica, Mexico & Nov 24, 1950 & $\mathrm{H}_{2} \mathrm{~S}$ & 22 \\
\hline London, England & Dec 5-9, 1952 & $\begin{array}{l}\mathrm{SO}_{2} \text { (particles) } \\
\mathrm{Up} \text { to } 0.004 \mathrm{~g} / \mathrm{m}^{3}\end{array}$ & 4000 \\
\hline London, England & June 3-6, 1955 & $\begin{array}{l}\mathrm{SO}_{2} \text { (particles) } \\
\mathrm{Up} \text { to } 0.002 \mathrm{~g} / \mathrm{m}^{3}\end{array}$ & 1000 \\
\hline New York, USA & Nov 24-30, 1966 & $\mathrm{SO}_{2}$ (particles) & 168 \\
\hline
\end{tabular}

example, the paper and metals processing industries of Tasmania, Australia have caused a receptor-based, 24 hour mean standard of $3 \mu \mathrm{g} / \mathrm{m}^{3}$ to be applied to arsenic; whereas most other governments have not chosen to legislate for this substance. Similarly, some Eastern European countries have chosen to legislate air quality standards for formaldehyde because of the extensive use of two-stroke engines in that region.

The following is a list of the nations researched or contacted directly: Argentina, Australia, ${ }^{1,6}$ Austria, ${ }^{7}$ Brazil, Canada, 1,8 Czechoslovakia, ${ }^{9}$ China, Commonwealth of Independent States (data from old USSR), Egypt, Finland, ${ }^{1}$ France, ${ }^{1}$ Germany, ${ }^{1,10}$ Greece, Hungary, ${ }^{11}$ India, Israel (enforce emissions only), Italy, ${ }^{1}$ Japan, ${ }^{1}$ Kenya, Korea, ${ }^{1}$ Kuwait, Mexico, ${ }^{9}$ New Zealand, ${ }^{1}$ Poland, Saudi Arabia, Singapore (uses WHO), South Africa, ${ }^{1,12}$ Switzerland, ${ }^{13}$ Taiwan, The Netherlands, ${ }^{1}$ United Kingdom, ${ }^{1}$ United States $^{1,2,14}$ and Yugoslavia (uses WHO as a guideline). A base standard used by many nations is the World Health Organization (WHO) ${ }^{15}$ and these values are included in Table II as a health-based guide. Those nations listed above, but not in Table II either use the WHO values or have no ambient air quality standards currently enforced. This Table should be read in conjunction with the following notes:

(i) Most nations subscribe to the "polluter pays principle" in their published philosophies.

(ii) Where a choice of standard is mandated by a country's responsible authority, the more stringent or "desirable level" has been chosen.

Table IIa. Ambient air quality standards currently applied in twenty-one nations for ozone, lead, fluorides and asbestos. All AAQS values in $\mu \mathrm{g} / \mathrm{m}^{3}$.

\begin{tabular}{|c|c|c|c|c|c|c|c|c|c|c|c|c|}
\hline \multirow{4}{*}{ COUNTRY } & dards & or some ti & he scal & & & $-\mathbb{N}$ & \multicolumn{6}{|c|}{ No receptor standards (emission standards may apply) } \\
\hline & \multicolumn{12}{|c|}{ SUBSTANCE } \\
\hline & \multicolumn{3}{|c|}{$\begin{array}{c}\text { Ozone } \\
\mathrm{O}_{3}\end{array}$} & \multicolumn{3}{|c|}{$\begin{array}{c}\text { Lead } \\
\mathrm{Pb}\end{array}$} & \multicolumn{3}{|c|}{$\begin{array}{c}\text { Fluorides } \\
\text { F }\end{array}$} & \multicolumn{3}{|c|}{ Asbestos } \\
\hline & $\begin{array}{l}\text { long } \\
\text { term }\end{array}$ & $\begin{array}{c}\text { medium } \\
\text { term }\end{array}$ & $\begin{array}{l}\text { short } \\
\text { term }\end{array}$ & $\begin{array}{l}\text { long } \\
\text { term }\end{array}$ & $\begin{array}{c}\text { medium } \\
\text { term }\end{array}$ & $\begin{array}{l}\text { short } \\
\text { term }\end{array}$ & $\begin{array}{l}\text { long } \\
\text { term }\end{array}$ & $\begin{array}{c}\begin{array}{c}\text { medium } \\
\text { term }\end{array} \\
\end{array}$ & $\begin{array}{l}\text { short } \\
\text { term }\end{array}$ & $\begin{array}{l}\text { long } \\
\text { term }\end{array}$ & $\begin{array}{c}\text { medium } \\
\text { term }\end{array}$ & $\begin{array}{l}\text { short } \\
\text { term }\end{array}$ \\
\hline $\begin{array}{l}\text { WHO } \\
\text { (1987) }\end{array}$ & & $100^{e}$ & $150^{g}$ & $0.5^{a}$ & & & & & & & & \\
\hline $\begin{array}{l}\text { Australia } \\
\text { Victoria (1981) } \\
\text { Tasmania (1974) }\end{array}$ & & $100^{e}$ & $240^{g}$ & $\begin{array}{l}1.5^{b} \\
1.5^{b}\end{array}$ & & & $\begin{array}{l}0.5^{b} \\
0.5^{b}\end{array}$ & $\begin{array}{l}2.9^{d} \\
2.9^{d}\end{array}$ & & & 33 fibre/l & \\
\hline Austria (1987) & & $100^{e}$ & $120^{h}$ & - & 一 & - & - & - & - & - & - & - \\
\hline Canada (1989) & $30^{a}$ & $30^{d}$ & $100^{g}$ & 一 & - & - & $0.2^{b}$ & $.085^{d}$ & & - & - & - \\
\hline Finland (1982) & 二 & - & - & - & - & - & - & - & - & - & - & - \\
\hline Germany (1986) & - & - & 二 & $2.0^{\alpha}$ & & & $1.0^{\alpha}$ & & $3.0_{\delta}^{h}$ & - & - & $\overline{-}$ \\
\hline Greece (1992) & - & - & - & $2.0^{a}$ & & & - & - & - & - & - & - \\
\hline Hungary (1990) & & $30^{d}$ & $60^{h}$ & & $0.3^{d}$ & $0.3^{h}$ & $3.0^{a}$ & $5.0^{d}$ & $20.0^{h}$ & & $5.0^{d}$ & $10^{h}$ \\
\hline Israel (1992) & & $160^{e}$ & $230^{h}$ & $\begin{array}{l}0.5^{a} \\
1.5^{b}\end{array}$ & $5.0^{d}$ & & - & - & - & & $0.4^{e}$ fibre $/ 1$ & \\
\hline Italy (1989) & - & - & - & - & - & - & 一 & - & $=$ & - & - & - \\
\hline Japan (1990) & & & $118^{g}$ & & & 0.1 & $=$ & - & - & & 10 fibre/1 & - \\
\hline Kuwait (1989) & & & $157^{9}$ & & $2.0^{d}$ & & - & - & - & - & - & - \\
\hline Mexico (1984) & & & $216^{g}$ & $1.5^{b}$ & & & - & - & - & - & - & - \\
\hline Netherlands (1986) & & & $120^{g}$ & $0.5^{a}$ & $2.0^{d}$ & & $0.8^{c}$ & $2.8^{d}$ & & - & - & - \\
\hline New Zealand (1986) & & $60^{e}$ & $120^{g}$ & $1.5^{6}$ & & & $\begin{array}{l}0.5^{b} \\
1.0^{k}\end{array}$ & & & - & - & - \\
\hline Poland (1990) & & $30^{d}$ & $100^{h}$ & $0.2^{a}$ & $1.0^{d}$ & & $1.6^{a}$ & $10.0^{d}$ & $30.0^{h}$ & - & - & - \\
\hline Saudi Arabia (1991) & & & $295^{g}$ & - & - & - & & $1.0^{d}$ & & - & - & - \\
\hline South Africa (1965) & & $100^{d}$ & $240^{g}$ & $2.5^{a}$ & & & - & - & - & - & - & - \\
\hline Soviet Union & & & 100 & .01 & & & & & 20 & 2.0 & & \\
\hline Switzerland (1985) & & & $\begin{array}{l}120^{g} \\
100_{\delta}^{h} \\
\end{array}$ & $1.0^{a}$ & & & - & - & - & - & - & - \\
\hline Taiwan (1975) & - & - & - & - & 二 & 二 & 一 & - & - & 一 & - & 二 \\
\hline United States (1990) & & & $240^{g}$ & $1.5^{b}$ & & & - & - & - & & 10 fibre/l & \\
\hline
\end{tabular}

Remarks:

a: annual mean; $b$ : 3-month mean; $c$ : 1-month mean; $d$ : 24-hour mean; $e$ : 8-hour mean; $f$ : 3-hour mean; $g$ : 1-hour mean; $h$ : 30-minute mean; $i$ : 15-minute mean; $j$ : 10-minute mean; and $k: 7$-day mean.

$\alpha: 99.99$ percentile; $\beta: 99.5$ percentile; $\gamma: 99$ percentile; $\delta: 98$ percentile; $\epsilon: 95$ percentile; and $\zeta: 50$ percentile. 
Table IIb. Ambient air quality standards currently applied in twenty-one nations for carbon monoxide, sulfur dioxide, nitrogen dioxide and particulate matter. All AAQS values in $\mu \mathrm{g} / \mathrm{m}^{3}$.

\begin{tabular}{|c|c|c|c|c|c|c|c|c|c|c|c|c|}
\hline No receptor st & adards & r some tir & ie scales & & - & No & eptor & tandards & missi & stan & ards may & pply) \\
\hline \multirow{3}{*}{ COUNTRY } & \multicolumn{12}{|c|}{ SUBSTANCE } \\
\hline & \multicolumn{3}{|c|}{$\begin{array}{c}\text { Carbon Monoxide } \\
\text { CO }\end{array}$} & \multicolumn{3}{|c|}{$\begin{array}{c}\text { Sulphur Dioxide } \\
\mathrm{SO}_{2}\end{array}$} & \multicolumn{3}{|c|}{$\begin{array}{c}\text { Nitrogen Dioxide } \\
\mathrm{NO}_{2} \\
\end{array}$} & \multicolumn{3}{|c|}{$\begin{array}{c}\text { Particulate Matter } \\
\text { PM }\end{array}$} \\
\hline & $\begin{array}{l}\text { long } \\
\text { term }\end{array}$ & $\begin{array}{c}\text { medium } \\
\text { term }\end{array}$ & $\begin{array}{l}\text { short } \\
\text { term }\end{array}$ & $\begin{array}{l}\text { long } \\
\text { term }\end{array}$ & $\begin{array}{c}\text { medium } \\
\text { term }\end{array}$ & $\begin{array}{l}\text { short } \\
\text { term }\end{array}$ & $\begin{array}{l}\text { Tong } \\
\text { term }\end{array}$ & $\begin{array}{c}\text { medium } \\
\text { term }\end{array}$ & $\begin{array}{l}\text { short } \\
\text { term }\end{array}$ & $\begin{array}{l}\text { long } \\
\text { term }\end{array}$ & $\begin{array}{c}\text { medium } \\
\text { term }\end{array}$ & $\begin{array}{l}\text { short } \\
\text { term }\end{array}$ \\
\hline $\begin{array}{l}\text { WHO } \\
(1987)\end{array}$ & & $10000^{e}$ & $\begin{array}{c}30000^{g} \\
60000^{h} \\
100000^{i} \\
\end{array}$ & & & $\begin{array}{l}350^{g} \\
500^{j}\end{array}$ & & $150^{d}$ & $400^{g}$ & & & \\
\hline $\begin{array}{l}\text { Australia } \\
\text { Victoria (1981) } \\
\text { Tasmania (1974) }\end{array}$ & & $\begin{array}{l}11400^{e} \\
12500^{e}\end{array}$ & $\begin{array}{l}34300^{g} \\
37500^{g}\end{array}$ & $50^{\alpha}$ & $\begin{array}{l}155^{d} \\
160^{d}\end{array}$ & $\begin{array}{l}445^{g} \\
450^{g}\end{array}$ & & $\begin{array}{l}120^{d} \\
120^{d}\end{array}$ & $\begin{array}{l}300^{g} \\
310^{g}\end{array}$ & $\begin{array}{l}90^{a} \\
90^{a}\end{array}$ & & \\
\hline Austria (1987) & & $10000^{d}$ & $40000^{g}$ & & $200^{d}$ & $200^{h}$ & & & $200^{h}$ & & $200^{d}$ & \\
\hline Canada (1989) & & $6000^{e}$ & $15000^{g}$ & $30^{a}$ & $150^{d}$ & $450^{g}$ & $60^{\alpha}$ & $200^{d}$ & $400^{g}$ & $60^{a}$ & $120^{d}$ & \\
\hline Finland (1982) & & $10000^{e}$ & $30000^{g}$ & $40^{a}$ & $200^{d}$ & $500^{g}$ & & $150^{d}$ & $300^{g}$ & $60^{\circ}$ & $150^{d}$ & \\
\hline Germany (1986) & $10000^{a}$ & & $30000_{\delta}^{h}$ & $140^{a}$ & & $400_{\delta}^{h}$ & $80^{a}$ & & $200_{\delta}^{h}$ & $150^{a}$ & & $300_{\delta}^{h}$ \\
\hline Greece (1992) & - & - & - & - & - & - & & & $200_{6}^{g}$ & - & - & - \\
\hline Hungary (1990) & $2000^{a}$ & $5000^{d}$ & $10000^{h}$ & $70^{a}$ & $150^{d}$ & $500^{h}$ & $70^{a}$ & $85^{d}$ & $100^{h}$ & $50^{a}$ & $100^{d}$ & $200^{h}$ \\
\hline Israel (1992) & & $11000^{e}$ & $60000^{h}$ & $60^{a}$ & $280^{d}$ & $500^{h}$ & & $560^{d}$ & $940^{h}$ & $75^{a}$ & $200^{d}$ & $300^{g}$ \\
\hline Italy (1989) & - & - & - & $40^{a}$ & $100^{d}$ & & $50_{\zeta}^{a}$ & & $200_{\delta}^{g}$ & $40^{a}$ & $100^{d}$ & \\
\hline Japan (1990) & & $\begin{array}{l}11400^{d} \\
22800^{e}\end{array}$ & & & $107^{d}$ & $267^{g}$ & & $80^{d}$ & & & $100^{d}$ & $200^{g}$ \\
\hline Kuwait (1989) & & $\begin{array}{c}9100^{d} \\
11400^{e}\end{array}$ & $40000^{g}$ & $80^{a}$ & $160^{d}$ & $453^{g}$ & & $100^{d}$ & & $90^{a}$ & $350^{d}$ & \\
\hline Mexico (1984) & & $14950^{e}$ & & & $341^{\alpha}$ & & & & $395^{g}$ & & $275^{d}$ & \\
\hline Netherlands (1986) & & $6000_{\delta}^{e}$ & $40000_{\alpha}^{g}$ & & $500^{d}$ & $830^{g}$ & & & $175^{g}$ & & $150^{\alpha}$ & \\
\hline New Zealand (1986) & & $10000^{e}$ & $40000^{g}$ & $50^{6}$ & $125^{d}$ & & & $100^{d}$ & $200^{g}$ & $60^{k}$ & & \\
\hline Poland (1990) & $120^{a}$ & $1000^{d}$ & $5000^{h}$ & $32^{a}$ & $300^{d}$ & $600^{h}$ & $50^{a}$ & $150^{d}$ & $500^{h}$ & $50^{a}$ & $120^{d}$ & \\
\hline Saudi Arabia (1991) & & $10000^{e}$ & $40000^{g}$ & $80^{a}$ & $365^{d}$ & $730^{9}$ & $100^{a}$ & & $660^{g}$ & $80^{a}$ & $340^{d}$ & \\
\hline South Africa (1965) & - & - & - & $80^{a}$ & $265^{d}$ & $780^{g}$ & $270^{a}$ & $540^{d}$ & $1080^{g}$ & & $150^{d}$ & $350^{g}$ \\
\hline Soviet Union & & & 20000 & - & - & - & 85 & & & 4 & & \\
\hline Switzerland (1985) & & $8000^{d}$ & & $30^{a}$ & $100^{d}$ & $100_{\varepsilon}^{h}$ & $30^{\alpha}$ & $80^{d}$ & $100_{\epsilon}^{h}$ & $70^{a}$ & $150_{\epsilon}^{d}$ & \\
\hline Taiwan (1975) & & $11400^{d}$ & $22900^{g}$ & $133^{a}$ & $267^{d}$ & & & $100^{d}$ & & $\begin{array}{l}240^{a} \\
210^{c} \\
\end{array}$ & & \\
\hline United States (1990) & & $10000^{e}$ & $40000^{g}$ & $80^{\alpha}$ & $365^{d}$ & $1300^{f}$ & $100^{a}$ & & & $50^{a}$ & $150^{d}$ & \\
\hline
\end{tabular}

\section{Remarks:}

$a$ : annual mean; $b$ : 3-month mean; $c$ : 1-month mean; $d$ : 24-hour mean; $e$ : 8-hour mean; $f$ : 3-hour mean; g: 1-hour mean; $h$ : 30-minute mean; $i$ : 15-minute mean; $j$ : 10-minute mean; and $k$ : 7-day mean.

$\alpha: 99.99$ percentile; $\beta: 99.5$ percentile; $\gamma: 99$ percentile; $\delta: 98$ percentile; $\epsilon: 95$ percentile; and $\zeta: 50$ percentile.

(iii) Those countries without a national standard, but with a state or provincial standard have those provincial standards shown in Table II (e.g., the sovereign states of Australia).

(iv) Some countries make the distinction that particulate matter of a diameter less than 10 microns is the chief concern for human health. Other nations do not give a size range and use a Total Suspended Particulate Matter (TSPM) standard. Some variation in mass density standards may result from this lack of clarity.

(v) The dashed regions indicate that no ambient air quality standard is currently enforced for that chemical in that nation, but an emission standard may apply. A clear region indicates no ambient air quality standard is enforced for that time scale only.

(vi) The receptor-based standards noted may be operating in conjunction with emission limit values. The focus of these data are ambient air quality standards.

It is worth noting here that the units of measurement specified in an ambient atmosphere regulation can influence public perceptions of an environmental health effect. For example, the asbestos limit for the United States is 10 fibres per litre. This appears to be a small number, yet it corresponds to 10,000 fibres $/ \mathrm{m}^{3}$. If we assume a daily intake of $20 \mathrm{~m}^{3}$ of air for an adult, the regulation limit corresponds to 200,000 fibres per day!

It will be noted in Table II that the vast majority of countries have chosen standards based on a simple mean concentration over some time period; usually derived from health and exposure considerations. However, some European nations have adopted a percentile of compliance approach which makes a direct comparison of data more difficult; particularly since the process is non-Gaussian.

\section{Receptor-Based Standards}

The monitoring of atmospheric chemical concentrations in population centers which may have both point and area sources of pollution is essential for the inhabitants' health. The atmospheric stability may be a favorable or an adverse parameter for the dispersion of undesirable chemicals. By ignoring the huge influence of the atmosphere's stability in setting a standard for concentrations at a receptor, the true mechanism of dispersion is not being recognized. As the atmosphere changes from being very stable to being well mixed and unstable, a plume contained within it will often change in pollutant concentration by many orders of magnitude. 


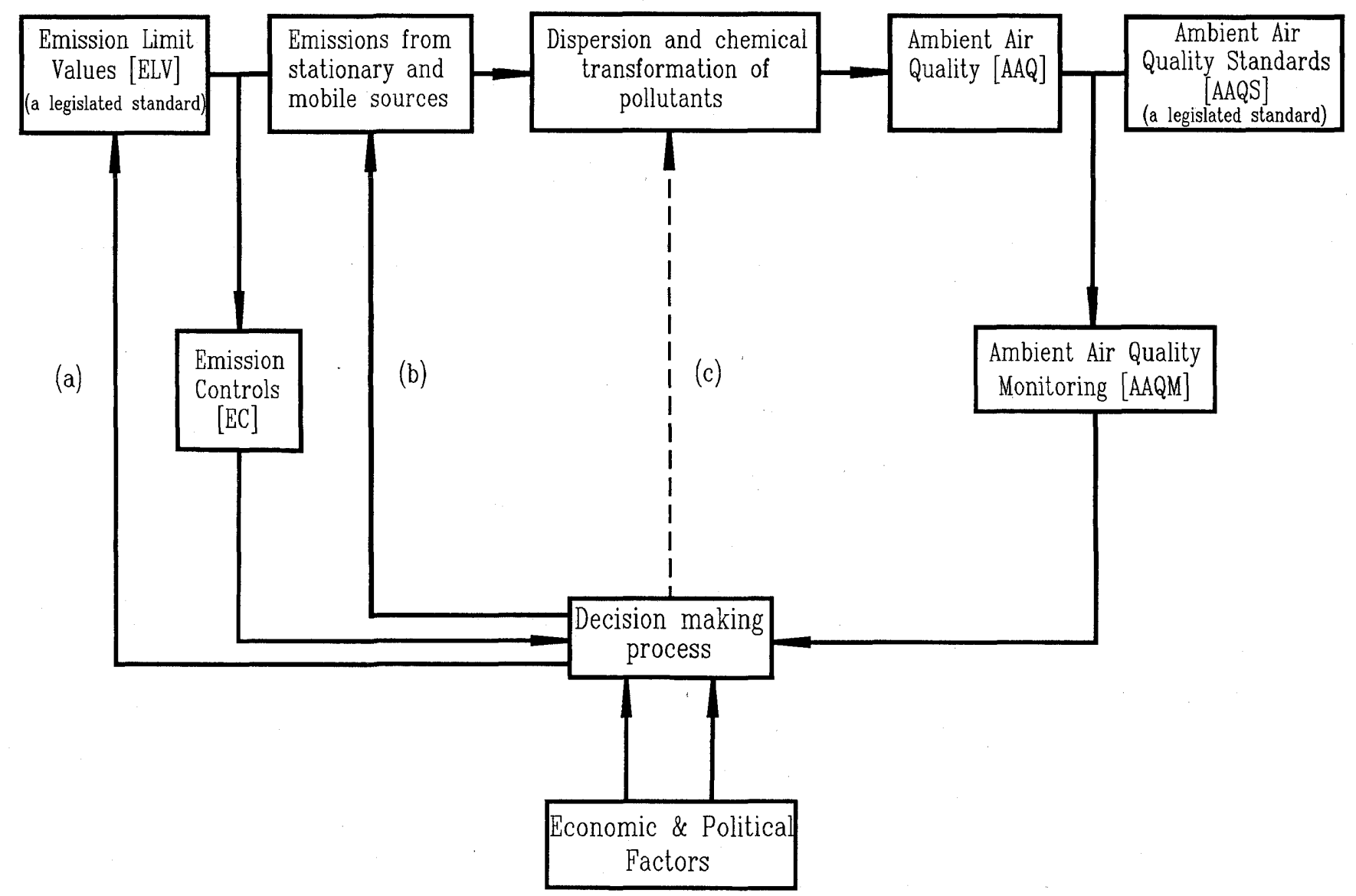

Figure 1. Flow chart of one possible ambient air quality management scenario. ${ }^{16}$

In addition to the atmospheric conditions, the local natural and anthropogenic topography will also have a great influence on the degree of dispersion. For example, the air mass over Mexico City is largely trapped inside a ring of mountains. Similarly, Denver, Colorado, often experiences high air pollution episodes during winter due to the combined effect of a very stable atmosphere and the restriction of air motion by the Rocky Mountains.

The total quantity of harmful chemicals discharged into the atmosphere may most easily be monitored at the source by emission restrictions on an industry by industry basis. This is the technique used in the United Kingdom. In a global sense, this approach will adequately monitor the "health" of the Earth's entire atmosphere. However, at a local level (such as for the citizens of Mexico City or Denver as noted above) the air quality must be monitored closely by the responsible authority using an ambient air quality approach.

\section{Monitoring Air Quality Standards}

During the compilation of data found in Table II it became apparent that there is an important distinction between having an air pollution standard (emission- or receptor-based) for a given substance and actually enforcing that requirement. From Table II it is apparent that the old Soviet Union had very stringent air quality guidelines; although the averaging period was not stipulated. However, the recent flow of information from the new Commonwealth of Independent States suggests that these standards were rarely enforced in their industrial cities.

Several countries have recently incorporated Ambient Air Quality Standards (AAQS) into their air pollution abatement strategies. These criteria are usually established primarily using health criteria such as: toxicity of the substance, duration of exposure and characteristics of the region to be protected (industrial, residential or pristine area). Actual ambient air quality is monitored and compared to these physiologically determined standards. When the levels are exceeded, decisions must be taken to restore the ambient air quality to acceptable values. Figure $1^{16}$ shows a schematic of this process and its dynamic nature is self evident. There are three ways, in this scenario, in which the decision making process may influence the ambient air quality.

(a) Modification of emission limit values (the mass flow rate deemed acceptable for that industry or vehicle) for stationary and mobile sources (point and area sources) which are usually based on the Best Available Technology (BAT) that is economically feasible. Additional considerations include the amount of the total emission of a pollution in a specified region. These measures generally assume that the sources of emissions in a given area are to meet the requirements imposed, while still taking into account the long-range regional/ continental (transboundary) air pollution which was not created in that area. In the case of a permanent lack of compliance with an Ambient Air Quality Standard a more stringent emission limit value is required.

(b) Direct control of emission sources permanently or for a given period of time. This may happen in episodic pollution cases for the reduction or elimination of pollution by the coordinated control of traffic and industrial sources. However, these measures should be considered and implemented as extraordinary cases only.

(c) Specification of the appropriate distance between the sources of emission and the area to be protected. Stack design, height and the requirements for physical (wind tunnel) or computational modeling of the dispersion process are important components to control proce- 
Table III. Ambient air quality priorities considered over a range of length scales (d).

\begin{tabular}{lcclc}
\hline \multicolumn{1}{c}{ Scale } & $\mathrm{d}[\mathrm{km}]$ & Significant Pollutants & Risk Involved & Control Criteria \\
\hline Local, Urban & $0-20$ & Contaminating Substances & Health & $\begin{array}{c}\text { Health related, short, medium } \\
\text { \& long-term AAQS } \\
\text { Regional }\end{array}$ \\
Continental & $20-200$ & $\begin{array}{c}\text { Contaminating Substances \& } \\
\text { Acidifying Substances }\end{array}$ & Health and Ecology & $\begin{array}{c}\text { Critical loads (depositions) } \\
\text { Target levels \& loads }\end{array}$ \\
Global & $>2000$ & Greenhouse Gases & Ecology & $\begin{array}{c}\text { Critical loads (depositions) } \\
\text { Target levels \& loads } \\
\text { Control of total amount of emis- } \\
\text { sions }\end{array}$ \\
\hline
\end{tabular}

dures. ${ }^{17-19}$ The pollutants would reach the area to be protected already diluted so as to comply with the required Ambient Air Quality Standards. These measures are incorporated in the prescriptions of regional planning and building requirements of residential areas and the siting of industrial enterprises.

The responsible authority must periodically check Emission Limit Values (ELV) for compliance. Such an Emission Control (EC) procedure is relatively common in many industrialized nations. The decision making process is influenced by economic and political factors that may well be hard to predict (costs to industry and pressures from society to reduce pollution, for example). Unfortunately, the time scales associated with this dynamic system are often quite long. However, a response to a serious pollution episode, shown by route (b), must occur in a time scale of only a few hours.

The determination of ambient air quality standards is an evolving process which depends on new research and the dissemination of that knowledge. The criteria established by health considerations are of prime importance for local/ urban air pollution, whereas ecological requirements dictate the regional/continental levels of these pollutants (i.e., acidification via sulphur and NOX compounds). Such a multi-level, air quality management philosophy is outlined in Table III.

\section{"Need to Know" Versus "Right to Know"}

In compiling this information, we found it easier to access the regulations from some countries as opposed to others. There is a major political difference between public rights to air quality information. ${ }^{20}$ In the United States, for example, the federal law mandates a "right to know," while the Seveso Directive (\#67/548) of the European community permits access based on a "need to know." This fundamental difference provides further impetus for an ambient based standard, in addition to emission based standards, since the public and other interested parties could monitor air quality at the property boundaries of an industrial facility.

\section{Conclusions}

For the general "health" of the Earth's atmosphere, an emission-based air quality standard is adequate. However, for the health of a local community a receptor-based ambient air quality standard must be monitored and enforced by an independent responsible authority. Many nations have no air quality standards at all; receptor- or emission-based. The ambient air quality standards for some of the more prominent pollutants are presented for twentyone countries that take a receptor-based approach to air quality management.

There is a significant range of ambient air quality standards between the countries reported. This may be attributed to factors as varied as the achievability of the nominated concentration in an industrial region, to the extent of local health research and the ever present influence of politics.

In addition, some nations have a zoning philosophy incorporated into the standards which makes a distinction between, say, industrial and pristine areas, or the degree to which a concentration is exceeded. Similarly, variations in the applied standard may occur in the case of episodic air pollution. In the USA there are three such episodic stages. These zoning and extreme event cases have not been addressed here.

It is hoped that more nations will monitor and regulate the ambient air quality, as well as regulate the gross emissions in their region. One possible procedure for this dynamic process is presented, along with how the pollutant varies its influence with the size of the region under consideration.

\section{Acknowledgments}

The authors wish to thank the following individuals and organizations for their help during the data collection process: Dr. Abdulbar A. Al-Gain of the Meteorology and Environmental Protection Administration, Kingdom of Saudi Arabia; Prof. Rumen Bojkov of the World Meteorological Organization; Prof. Humberto Bravo of Centro de Ciencias de la Atmósfera, Mexico; Mike Bulley of the Auckland Environmental Protection Agency Limited; Prof K. K. Chin of the National University of Singapore; H. Croze of the United Nations Environment Programme; Elizabeth English of the University of Pennsylvania; Prof. Ing. Giuseppe Ferraiolo of Comitato Nazionale di Studio per l'Inquinamento Atmosferico; Dr. Michael Graber of the Air Quality Division, Ministry of the Environment, Israel; Gordon H. Grange of the South African National Association for Clean Air; Ibrahim M. Hadi of the Environment Protection Council of Kuwait; Dr. John Harry of the Clean Air Society of Australia and New Zealand; Jim Haskill of Environment Canada Conservation and Protection, Industrial Programs Branch; Prof. Tsu-Chang Hung of the Academia Sinica, Taiwan; Dr. Aleksandar Knežeric of the IPES Institut, Yugoslavia; S. Misaka of the Japanese Industrial Pollution Control Association; A. Sann of the Tasmanian Department of Environment and Planning; United Kingdom National Society for Clean Air and Environmental Protection; Prof. Dmitrii Vinogradov of the Moscow Institute of Civil Engineering; Anh Tuan Vu of the United Nations Environment Programme; Dr W. Werner of Din Deutsches Institut Für Normung E. V. Verein Deutscher Ingenieure VDI, Germany; G. J. R. Wolters of the Ministry of Housing, Physical Planning and Environment, Netherlands.

Dallas McDonald and Bryan Critchfield edited and prepared the final version of this paper. Endre Kovács would like to acknowledge the United States Information Agency for providing a grant to Colorado State University and the Technical University of Budapest under a project entitled, "Educational Exchange for Environmental Protection." Partial support for this paper was provided by the National Park Service through Interagency Agreement \#0475-4. 
8003 with the National Oceanic and Atmospheric Administration through Agreement \#CM0200 DOC-NOAA to the Cooperative Institute for Research in the Atmosphere (Project \#5-31253), and the National Science Foundation Grant \#BCS-8821542.

\section{References}

1. Barker, I.; Barker, J., Ed. Clean Air Around the World; The Law and Practice of Air Pollution Control in 14 Countries in 5 Continents, International Union of Air Pollution Prevention Associations, Breighton, England 1988.

2. Seinfeld, J. H., Atmospheric Chemistry and Physics of Air Pollution, John Wiley and Sons, 1986.

3. Heidorn, K. C., "A chronology of important events in the history of air pollution meteorology to 1970," Bull. Amer. Meteorol. Soc. 59: 1584 (1978).

4. 1990 IUAPPA Handbook, International Union of Air Pollution Associations, 1990.

5. "A Directory of Information Sources on Air and Water Pollution," United Nations Environment Programme, Industry and Environment Office, Paris, 1989.

6. "Victorian Government Gazette," Victorian State Government, Australia, Number 63, July 1981, p. 2295-2300.

7. "Bundesgesetzblatt (Federal Register)," Number 161, Republic of Austria (in German), 1987.

8. "Canada Gazette Part 1," Department of the Environment, Annexation to the Environmental Protection Act, Canada, 1989 , p. $3642-3645$.

9. "La Contaminación del Aire en México," Primera Edición, Fundación Universo Veintiuno, A.C., México, 1987.

10. "Bundesimmissionsschutzgesetz TA-Luft (Federal Clean Air Act, Technical Guidelines-Air)," Federal Republic of Germany (in German), 1986.

11. "Regulation on the Air Polluting Substances, Ambient Air Quality Criteria and on the Monitoring of Ambient Air Quality," Republic of Hungary, 5/1990 (X11.6) NM and MSZ 21854-1990.
12. "Draft Air Pollution Control Policy," Department of National Health and Population Development, Pretoria, South Africa.

13. "Luftreinhalte Verordnung (Regulations on Clean Air)," Swiss Confederation (in German), 1985.

14. "National Air Quality Standards," Code of Federal Regulations, 40, Protection of Environment, Part 50, Sections 50.4 to 50.11, United States Government Printing Office, 1974.

15. "Air Quality Guidelines for Europe," World Health Organization Regional Publications, European Series No. 23, Copenhagen, 1987.

16. Kovács, E.; Rymorz, P.; Sárdy, G., "Control Mechanism of Environmental Protection," Energy Management 16: 262 (in Hungarian), (1975).

17. Cermak, J. E. "Application of Fluid Mechanics to Wind Engineering," A Freeman Scholar Lecture, Journal of Fluids Engineering, American Society of Mechanical Engineers, Volume 97, Number 1, March 1975.

18. Szepesi, D. J. "Compendium of Regulatory Air Quality Simulation Models," Akadémiai Kiadó, 518 pages, Budapest, 1989.

19. Zanetti, P. Air Pollution Modeling, Computational Mechanics Publication, Southampton and Boston, 1990.

20. Renn, O. "Risk communication at the community level: European lessons from the Seveso Directive," JAPCA 39: 1301 (1989).

21. "Meteorology and Atomic Energy-1968," Technical Information Center, United States Department of Energy, January 1980 .

L. S. Cochran is with the Civil Engineering Department and R. A. Pielke is with the Department of Atmospheric Science, Colorado State University, Fort Collins, CO 80523. E. Kovács is with the Institute for Environmental Protection, Budapest, Hungary. This manuscript was submitted for peer review on June 2, 1992. The revised manuscript was received on August 3, 1992. 